\title{
Impact of Gender Discrimination on Professional life of Working Women in Education Sector of Haryana Universities
}

\author{
Deepa Sharma, C. Venkateswaran,
}

\begin{abstract}
The Gender discrimination is a very live issue of remains current issues especially in concern of India. We proudly announces in today era both genders are equally treated on homes as workplaces also but it is a harsh reality of today's world women are not get equality on the workplaces. It is fact women come out from homes boundaries and financially support to their family. We all know about this fact education is a backbone of every developed country So mostly women make their career in teaching professions. In education sector treated unfairly female faculty as compare to male faculty. In India discrimination is started from birth of the girl child. Mostly women and girls spend their times to do the household work, caring children and kitchen work. Today era women to do the work as equal to men but women play a critical role to maintain the balance between their personal and professional life. Many factors and forms of discrimination affected the women personal and professional life. In education sector not rest from the discrimination. Female faculty facing the discrimination in case of recruitment, selection, salary and promotion. Gender discrimination Influences the women employees because in Indian society wrong perception about the women. According to society women are physically and mentally weak as comparison to male. Males are physically and mentally strong and they are take effective decisions. Females are full of emotions they can't take effective decisions as compare to males. So in this research we focus on how working women facing the personal and professional problems in their life. How to women maintain balance between their personal and professional life.
\end{abstract}

Keywords : Gender discrimination, Working women issues and challenges, Status of women in society, Working women in India.

\section{INTRODUCTION}

Everybody knows gender discrimination is present in every field. Mostly discrimination affected directly or indirectly women professional and personal life. Several studies done about the presence of gender discrimination on the workplace. Women mostly preference to teaching profession

Revised Manuscript Received on February 05, 2020.

* Correspondence Author

Deepa Sharma*, Department of Management, Maharishi Markandeshwar (Deemed to be University), Mulllana, India Email: deepasharma36099@gmail.com Markandeshwar (Deemed to be University) Mullana, India, Email: sd0007430@gmail.com

(C) The Authors. Published by Blue Eyes Intelligence Engineering and Sciences Publication (BEIESP). This is an open access article under the CC BY-NC-ND license (http://creativecommons.org/licenses/by-nc-nd/4.0/)
Dr. C. Vankateswaran, Department of Management, Maharishi

and their relatives \& parents supporting also to doing job in education sector. Some women thought the married women faced more problems as compared to unmarried women. Many respondents deny the gender equality concept because directly and in directly they go through from in daily life. Gender discrimination is a critical concept. The many valuable review of literature shows to much gender inequality between them of many domains like education, life experience, interests, wok experience and careers etc. Mostly women are choosing their career in education sector because they think easily maintain their personal and professional life. Perspective of family and husband also feel comfortable to join the education sector by women.

Mostly Indian society is male dominated. In modern time women came out of homes because of financially support to their families. Women play a vital role in their life. She plays a many character in family as like a daughter, mother of children's, as a wife and as an employees etc. Every good mother always becomes a good manager. Does not mean a working women not manage the family properly or leave the family responsibilities because of she wants to become their career successfully. In this study we mostly focus on which types of problems and obstacles facing by women in their career. In the education sector women face the inequality directly and indirectly manner. Women facing the discrimination in the recruiting, selection and promotion time. Some time women facing the discrimination in many forms like caste, age, color and region. In any workplace may be as a teaching profession discrimination exist in every filed mostly effected the women. Many factors like cultural, legal, economic and geographical affected and raised the discrimination. Main reason of discrimination affected the women because women not take the initiative own self and not take the initiative toward own right makes by government in favor of women. As result female faculty as compare to male faculty discriminated in education sector. So women get less importance on workplace. Some time women to much successful because of their more hard work and men are not comfort to do the work under the women as result men's ego hurt. Every workplace gender bias creates because lacks of knowledge about their rights, point of view of men, society prospective any other reasons etc. Working women facing too much personal and professional problems and obstacles during the performs tasks. After doing the job when working women return home at evening and she has performed household works. In other way men never helps the household works or not any contribution to do the household work.

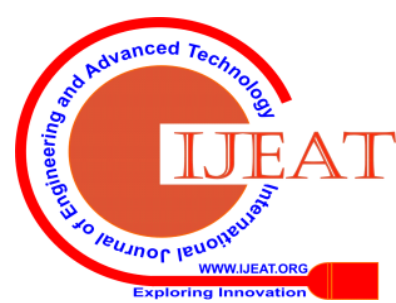




\section{A. Problem faced by working women on the workplace}

A gender bias creates at the workplace. Women's workers in India faced many problems and challenges during the job. In India mostly women's do household work like house cleaning, cooking washing cloths and care of children etc ,but men not give any contribution in household works.

Except the basic needs to provide the good educations to children's, to handle health problems and others factors influence the life. Money is a key of to fulfill the all requirements of life so women's are also contribute to the family as a financially. Women's came out the home may be they are educated or may not be. To survive the life and provides to their children's to better life. They are doing the jobs. On the workplaces women's suffering from many problems and challenges. So below figure 1.1 we discuss about all problems and challenges one by one.

\author{
Disturb mind \\ Lack of security \\ No support by In-laws and husbands \\ Lack of facilities \\ Job insecurity \\ Adjustment the workplace environment \\ Job time \\ Salary gap \\ Lack of time for family
}

Figure 1.1 -: By Author

Disturb-mind-: On the workplace a women faced the too much stress because every working woman alone manage the household work and workplace work. She maintains the balance between her personal life and professional life but an employer can't understand her problem, an employer only demand and expectation from there the good work. So women's are fully stressful and mentally upset.

Lack of security-Some Time by the employers feels the women's uncomfortable on the workplace under the law it's a crime. An employer does the unethical behavior with them. Women's always should be to take strictly step against the employers.

No support by In-laws and husbands -In modern era men thinks they are more caliber to performed the tasks rather than women's but this statement is not true as like a men's ,women's also doing the task efficiently and effectively but by employers underestimate their performance.

Lack of facilities-Women's not only faced the problem within the organization ,same challenges and problems daily faced during the travelling from home to workplace duration. Lack of Family Support- Women's give her hundred percent to financially contribution but sometimes women's caliber underestimate by their family members. Willingly family members not support them.

Job insecurity-We are human beings suffering from health problems in case of women's when they want to leave regarding maternity but employers not willingly provide the leaves.

Job security- As compare to men's, women's performance no count. Employers think women's are not physically strong as compare to men's So men also had more opportunities of higher salary, promotions etc benefits provides the men's.

Job time- Always women's are doing the compromise and adjustment in life. They are known, gender discrimination arises on the workplace, Unequal pay but they are not strictly step against the employers.

Working hours- A single women plays a many role in our life as like a mother, as like a wife and as an employee or working women but her duties not off whole life. So working hours not in her favor but she compromise.

Salary gap- Today is modern era but on the workplace women's are not equally treated by employers. Unequal pay, unethical behavior suffering by women's on workplace.

Lack of time for family - Sometime unhealthy environment provides by the employers so women's are not fully secure but to fulfill the basics needs they doing the job in this unethical environment.

\section{B. Reasons of gender discrimination on the workplace}

Sex and gender both are different in origin but physically role of individuals must have to be used his/ her mentally thinking in order to move in the society. Gender discrimination means on the workplace different ways to be used to treat a men and women powers. About the women's our backward thinking is women's are weak physically and mentally. They are emotionally based take the all decisions. Women's are not mentally strong as compare to men's to take efficiently decisions. Gender discrimination reasons, factors and causes are too much describe through the figure 1.2.

Causes-:

Age

Sex ratio

Experience

Social customes,belief and practices

Social attitude

Lack of awareness of women rights

Region

Caste

Color

Culture

Male dominated society

Roles \& Positions

Demographic reasons

Nationality

Geographic reasons

Factors-:

Social factors

Cultural factors

Legal factors

Economic factors

Internal factors

External factor

Figure no.1.2-:All causes, reasons and factors of gender discrimination

\section{Review literature}

It's a harsh reality about gender discrimination. We very proudly announced that we live in $21^{\text {st }}$ Century.

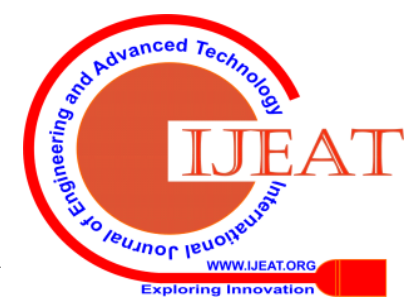


Today era both genders are equally but it's a half truth of reality. Many studies have done about gender discrimination. Women's too much problems faced during the jobs. As result of women feels stress and dissatisfaction in their jobs.

In this studies we find out women come out the homes and give the financial support to their families. Mostly women joining the education sector to satisfied their needs, desires and wants. Today era women are give their full contribution in their professional life but they suffering from gender inequality. Behind the gender discrimination is lack of information about their rights; lack of confidence and lack of initiative towards their interests as result discrimination is broad issues out of remain issues. Gender inequality takes a big shape and live issue in today world. Many Indian and international authors work on this topic. Fully focused on inequality issues put the bad impact on women's professional and personal life. Female faculties who working in education sector have experience about discrimination, as result they not perform their duties with interest. Women have negative experience about their jobs (Daniel, 2014). Female feels very disappointed during the jobs facing discrimination. In India women facing inequality birth of girl child. In India when girl take the birth discrimination begin. Male boys give more preference as compare to girl child. Girl child helps to their mother (Samidha Pokharel, 2008) to do the household work like, clean dishes, cleaning floors and washing the clothes. Women to maintain the work life balance. They have many shades in their life, as result they are mentally upset and depressed and fully not concentrate on their jobs and family. Some time women critically need of finance or monetary resources so they are bound to do the jobs (Jafar Hassanzadeh, 2014) because of financial need. So they are felt discrimination during the jobs but they are helpless to do the jobs. They are continuing the job in pressure or biased environment. Women perform their duties and responsibilities with full dedication and honesty. Through the findings we also give more attention on which types of problems and issues facing by married and unmarried women. Today women not successfully manage their family also as to as their professional life and their career (Yang Lydia Yang, Ph.D., Kansas State University 2016). In every profession every women facing discrimination in many forms like, religious, cultural, race, economic and socially. (Kea G. Tijdens2009).Many factors create a trouble for women to perform the duties during the jobs. During the questionnaire many respondents share their experience about discrimination. Questionnaires too much supportive to find out the reality of discrimination by respondents.

Discrimination faced by women from their home to against the inequality (Mrs. G.kanthisree, M.B.A., M.Phil. 2013).Some time women and men have same education and designation but as compare to men they facing inequality in terms of salary, status and positions. In education sector female faculty not feel safe because of harassment, insecurity, mentally depressed and upset.

To identify the perception, idea and importance of Job/Career in women's life. To examine the achieve of family support and performance guide of working women. To imagine the problems faced by female worker due to gender bias in their relevant work place (Sushma Nichani, 2013).To analyze the gap between actual and standard expectations to job satisfaction among working women (Daniel E Gberevbie, 2014).To recognize the obstacles and problems faced by workplace. But women mostly not take the strictly steps

women. To analyze the factors influences the female works on the workplace .To identify the wage gap factors (Dr. K Rajam, 2018).

Every working woman facing lots of troubles in their life's related to their personal and professional life. Some time the wants to monetary support to their family and provide better life to their children's so women doing the jobs. In education sector female faculty to performing their tasks under the male boss, they not cooperate with her. If male faculty under the working of female boss try to pressurize the women and behave rudely with them because of their ego problem. In both cases only on suffering the women and, as result they quit from job otherwise lose their confidence.

To compare the work life balance between married and unmarried women employees and identify the cause of problem related to their personal and professional life. To analyze the impact of women's office performance on women's family and how women to do efforts to make their personal and professional life smoothly (Meenakshi Maheshwari, 2019).

In this paper we study about how to treat university female faculty and which types of facilities provide by universities during the jobs and maternity leaves. What role of educational sector in contribution of female faculty's personal growth and development. (Manasi Tiwari, 2018) What steps taken by universities to remove the inequalities happened in education institutions. Which types of factors are related to working conditions, or opportunity structures in the universities?

\section{PROBLEM STATEMENT}

The problem of this study is to find the equally treated the women and men in the education se sector. How to Gender discrimination makes an issues in career of working women. Which types of problems and obstacles facing by women in their Personal and Professional life?

\section{Objectives of study-:}

To examine the problems faced by female faculty in their professional life.

To study the impact of gender discrimination on female faculty career growth in education sector.

To identify the forms of discrimination impact on female faculty in education sector.

To find the personal and professional problems and obstacles because of their jobs doing in education sector.

\section{Independent variables}

Problems and obstacles faced by female faculty in Education sector.

Gender inequalities facing by female faculty during the recruitment and selection process.

Inequality create problems and obstacles in job/career growth of women.

\section{Dependent variables}

Gender discrimination in Education sector

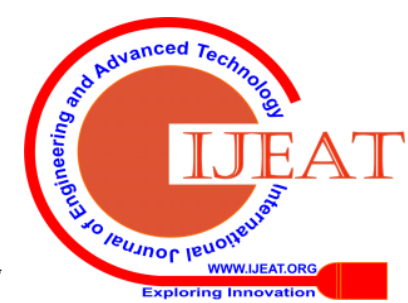




\section{Impact of Gender Discrimination on Professional life of Working Women in Education Sector of Haryana}

Universities

\section{Research methodology and research framework-:}

Research Methodology is a process to find the fact about a particular problem. To search the facts of problems some methods and ways adopted by the researcher that's ways and methods called research methods. Our basic idea is to study the gender discrimination in education sector in each country and contribution in economic growth. This study will adopt an analytical and descriptive approach based on observations \& quessinaaries. Present study has been carried out in many districts of Haryana Yamunanagar, Ambala, and krukshetra. Female faculty faced discrimination by male management because our Indian society is male dominated. Sometime women's never take initiative about their rights. As result women not performing their tasks properly and not satisfied their jobs. Primary data was used in the study. Required information was collected with the help of a well -structured questionnaires. Questionnaires for the study contained open ended \& close ended questions. Data should be collected used to be questions to study the factors. Likert -scale depicts the value 1 for strongly agree and 5 for strongly disagree. Data should be gathering or collecting through the questionnaires from 250 respondents and 300 found suitable for studies. Recommendations and suggestions have been taken from the pilot survey, after that questionnaires revised.

\section{Problem analysis through exploratory research design:}

Exploratory research design helps to researcher to explore the hidden things. Hidden things related to inequality in universities come in light to take the interviews of female faculty staff. As result they share their experience about the gender discrimination.

\section{Assuming the hypothesis through casual design:}

This design helps to researchers to set up and identify the hypothesis. Those methods should be helps to gathering the data to find the accurate result and show the causal effect about the variables. Shows the cause and effects relations of variables.

\section{Analysis the data through statistical tools:}

Statistical tools should be used to get the accurate result of collected data. In others words we can say that analyzing the collected data. SPSS is software helps to analysis the collected data and gets the practical recommendations or result.

\section{Hypothesis-:}

1. H0 = Education sector no working environment in favor of professional women.

H1 = Education sector no working environment in favor of professional women.

2. HO = Inequality does not created by Management or seniors.

H1 = Inequality does created by Management and seniors 3. $\mathbf{H 0}=$ Complexity of the problems is not more of unmarried women.

H1 = Complexity of the problems is more of unmarried women.

4. $\mathbf{H 0}=$ Relatives attitudes towards working married women does not created problems for female faculty.

H1 = Relatives attitudes towards working married women does creates problems for female faculty. from female faculties of universities. Likert -scale has been

5. Ho = Female faculty are not highly ignored in Government Universities.

H1 =Female faculty are highly ignored in Government Universities

6. Ho = Gender inequality is not a major problem remains of out of other problems.

H1 = Gender inequality is a major problem remains of out of other problems.

7. $\mathbf{H O}=$ Favoritism is not the problem during the recruitment and training period.

H1 = Favoritism is the problem during the recruitment and training period.

8. H0= Government Universities is not suitable for female Workers

H1 = Government Universities is suitable for female workers.

\section{Data structuring-:}

This study will adopt an analytical and descriptive approach based on observations \& quessinaaries. Present study has been carried out in many districts of Haryana Yamunanagar, Ambala, and krukshetra. Female faculty faced discrimination by male management because our Indian society is male dominated. Regarding data collection, information is collected through questionnaires from 305 respondents from the various district of Haryana government universities.

Respondents Demographic Characteristics

Table 1:Frequency table of age

\begin{tabular}{|ll|l|l|l|l|}
\hline \multicolumn{2}{|l|}{ Variables } & $\begin{array}{l}\text { Frequ } \\
\text { ency }\end{array}$ & $\begin{array}{l}\text { Perce } \\
\text { nt }\end{array}$ & $\begin{array}{l}\text { Valid } \\
\text { Percent }\end{array}$ & $\begin{array}{l}\text { Cumulat } \\
\text { ive } \\
\text { Percent }\end{array}$ \\
\hline \multirow{4}{*}{ Valid } & 21 -25years & 121 & 39.7 & 39.7 & 39.7 \\
& 26-30years & 84 & 27.5 & 27.5 & 67.2 \\
& 31-35years & 70 & 23.0 & 23.0 & 90.2 \\
& 36-40 years & 30 & 9.8 & 9.8 & 100.0 \\
& Total & 305 & 100.0 & 100.0 & \\
\hline
\end{tabular}

Table 2:Frequency table of gender

\begin{tabular}{|ll|l|l|l|l|}
\hline & & $\begin{array}{l}\text { Freq } \\
\text { uen } \\
\text { cy }\end{array}$ & Percent & $\begin{array}{l}\text { Valid } \\
\text { Perce } \\
\text { nt }\end{array}$ & $\begin{array}{l}\text { Cum } \\
\text { ulativ } \\
\text { e } \\
\text { Perce } \\
\text { nt }\end{array}$ \\
\hline \multirow{4}{*}{ Valid } & female & 300 & 98.4 & 98.4 & 98.4 \\
& 2.00 & 1 & .3 & .3 & 98.7 \\
& 3.00 & 4 & 1.3 & 1.3 & 100.0 \\
& Total & 305 & 100.0 & 100.0 & \\
\hline
\end{tabular}

Table 3: Frequency table of qualification

\begin{tabular}{|ll|l|l|l|l|}
\hline \multicolumn{1}{|l|}{ Variables } & $\begin{array}{l}\text { Frequ } \\
\text { ency }\end{array}$ & Percent & $\begin{array}{l}\text { Valid } \\
\text { Percent }\end{array}$ & $\begin{array}{l}\text { lum } \\
\text { ulativ } \\
\text { e } \\
\text { Perce } \\
\text { nt }\end{array}$ \\
\hline \multirow{4}{*}{ Valid } & Diploma & 82 & 26.9 & 26.9 & 26.9 \\
& Graduation & 80 & 26.2 & 26.2 & 53.1 \\
& PG & 79 & 25.9 & 25.9 & 79.0 \\
& Ph. D & 64 & 21.0 & 21.0 & 100.0 \\
& Total & 305 & 100.0 & 100.0 & \\
\hline
\end{tabular}

Table 4: Frequency table of marital status 


\begin{tabular}{|ll|l|l|l|l|}
\hline Variables & & $\begin{array}{l}\text { Freque } \\
\text { ncy }\end{array}$ & $\begin{array}{l}\text { Percen } \\
\mathrm{t}\end{array}$ & $\begin{array}{l}\text { Valid } \\
\text { Percen } \\
\mathrm{t}\end{array}$ & $\begin{array}{l}\text { Cumulat } \\
\text { ive } \\
\text { Percent }\end{array}$ \\
\hline \multirow{4}{*}{ Valid } & Unmarried & 71 & 23.3 & 23.3 & 23.3 \\
& Married & 83 & 27.2 & 27.2 & 50.5 \\
& Widowed & 66 & 21.6 & 21.6 & 72.1 \\
& Divorced & 85 & 27.9 & 27.9 & 100.0 \\
& Total & 305 & 100.0 & 100.0 & \\
\hline
\end{tabular}

Table 5: Frequency table of Husband job status

\begin{tabular}{|ll|l|l|l|l|}
\hline Variables & $\begin{array}{l}\text { Freq } \\
\text { uenc } \\
\mathrm{y}\end{array}$ & Percent & $\begin{array}{l}\text { Valid } \\
\text { Percent }\end{array}$ & $\begin{array}{l}\text { Cumul } \\
\text { ative } \\
\text { Percen } \\
\mathrm{t}\end{array}$ \\
\hline \multirow{4}{*}{ Valid } & An employer & 97 & 31.80 & 31.80 & 31.80 \\
& Business man & 90 & 29.50 & 29.50 & 29.50 \\
& Others & 118 & 38.70 & 38.70 & 100.0 \\
& Total & 305 & 100.0 & 100.0 & \\
\hline
\end{tabular}

Table 6: Frequency table of number of family members

\begin{tabular}{|ll|l|l|l|l|}
\hline Variables & $\begin{array}{l}\text { Freque } \\
\text { ncy }\end{array}$ & Percent & $\begin{array}{l}\text { Valid } \\
\text { Percent }\end{array}$ & $\begin{array}{l}\text { Cumulat } \\
\text { ive } \\
\text { Percent }\end{array}$ \\
& & & & & \\
\hline \multirow{2}{*}{ Valid } & $2-4$ & 80 & 26.2 & 26.2 & 26.2 \\
& $>4-6$ & 87 & 28.5 & 28.5 & 54.8 \\
& $>6-8$ & 74 & 24.3 & 24.3 & 79.0 \\
& $>8-10$ & 64 & 21.0 & 21.0 & 100.0 \\
& Total & 305 & 100.0 & 100.0 & \\
\hline
\end{tabular}

Table 7: Frequency table of family status

\begin{tabular}{|ll|l|l|l|l|}
\hline Variables & $\begin{array}{l}\text { Freque } \\
\text { ncy }\end{array}$ & $\begin{array}{l}\text { Percen } \\
\mathrm{t}\end{array}$ & $\begin{array}{l}\text { Valid } \\
\text { Percen } \\
\mathrm{t}\end{array}$ & $\begin{array}{l}\text { Cumul } \\
\text { ative } \\
\text { Percen } \\
\mathrm{t}\end{array}$ \\
\hline \multirow{2}{*}{ Valid } & $\begin{array}{l}\text { Joint family } \\
\text { Nuclear family }\end{array}$ & 149 & 48.9 & 48.9 & 48.9 \\
& Total & 305 & 51.1 & 51.1 & 100.0 \\
& & 100.0 & 100.0 & \\
\hline
\end{tabular}

Table 8: Frequency table of family income per annum

\begin{tabular}{|ll|l|l|l|l|}
\hline Variables & & $\begin{array}{l}\text { Freq } \\
\text { uenc } \\
\mathrm{y}\end{array}$ & $\begin{array}{l}\text { Percen } \\
\mathrm{t}\end{array}$ & $\begin{array}{l}\text { Valid } \\
\text { Percent }\end{array}$ & $\begin{array}{l}\text { Cumul } \\
\text { ative } \\
\text { Percen } \\
\mathrm{t}\end{array}$ \\
\hline \multirow{5}{*}{ Valid } & < 50 thousand & 78 & 25.6 & 25.6 & 25.6 \\
& >50000-2 Lac & 73 & 23.9 & 23.9 & 49.5 \\
& >2 Lac -5 Lac & 88 & 28.9 & 28.9 & 78.4 \\
& >5 Lac & 66 & 21.6 & 21.6 & 100.0 \\
& Total & 305 & 100.0 & 100.0 & \\
\hline
\end{tabular}

Table 9: Frequency table of residence status

\begin{tabular}{|ll|l|l|l|l|}
\hline Variables & $\begin{array}{l}\text { Frequ } \\
\text { ency }\end{array}$ & Percent & $\begin{array}{l}\text { Valid } \\
\text { Percent }\end{array}$ & $\begin{array}{l}\text { Cum } \\
\text { ulativ } \\
\text { e } \\
\text { Perce } \\
\text { nt }\end{array}$ \\
\hline \multirow{4}{*}{ Valid } & Rural & 78 & 25.6 & 25.6 & 25.6 \\
& Urban & 81 & 26.6 & 26.6 & 52.1 \\
& Semi-Rural & 67 & 22.0 & 22.0 & 74.1 \\
& Semi-Urban & 78 & 25.6 & 25.6 & 99.7 \\
& 11.00 & 1 & .3 & .3 & 100.0
\end{tabular}

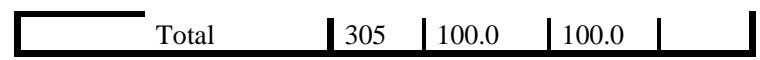

Table 10: Statistics of respondent's demographics (1-9)

\begin{tabular}{|c|c|c|c|c|}
\hline & Age & Gender & Qualification & $\begin{array}{l}\text { Marital } \\
\text { Status }\end{array}$ \\
\hline Valid & 305 & 305 & 305 & 305 \\
\hline Missin & O & O & 0 & \\
\hline g & 0 & 10 & 0 & 0 \\
\hline Mean & 2.0295 & 1.0295 & 2.4098 & 2.5410 \\
\hline Std. Error of Mean & .05789 & .01343 & .06281 & .06467 \\
\hline Median & 2.0000 & 1.0000 & 2.0000 & 2.0000 \\
\hline Mode & 1.00 & 1.00 & 1.00 & 4.00 \\
\hline Std. Deviation & 1.01102 & .23462 & 1.09690 & 1.12936 \\
\hline Variance & 1.022 & .055 & 1.203 & 1.275 \\
\hline Skewness & .517 & 8.079 & .096 & -.006 \\
\hline $\begin{array}{l}\text { Std. Error of } \\
\text { Skewness }\end{array}$ & .140 & .140 & .140 & .140 \\
\hline Range & 3.00 & 2.00 & 3.00 & 3.00 \\
\hline Minimum & 1.00 & 1.00 & 1.00 & 1.00 \\
\hline Maximum & 4.00 & 3.00 & 4.00 & 4.00 \\
\hline
\end{tabular}

Table 10: Statistics of respondent's demographics (1-9)

\begin{tabular}{|l|l|l|l|l|}
\hline $\begin{array}{l}\text { Husband } \\
\text { job }\end{array}$ & $\begin{array}{l}\text { No. of } \\
\text { family } \\
\text { members }\end{array}$ & $\begin{array}{l}\text { Family } \\
\text { status }\end{array}$ & $\begin{array}{l}\text { Family } \\
\text { annual } \\
\text { income }\end{array}$ & $\begin{array}{l}\text { Residentia } \\
\text { area }\end{array}$ \\
0 & 305 & 305 & 305 & 305 \\
1.4852 & 0 & 0 & 0 & 0 \\
.02866 & 2.4000 & 1.5115 & 2.4656 & 2.5049 \\
1.0000 & .06241 & .02867 & .06265 & .07045 \\
1.00 & 2.0000 & 2.0000 & 3.0000 & 2.0000 \\
.50060 & 2.00 & 2.00 & 3.00 & 2.00 \\
.251 & 1.09003 & .50069 & 1.09408 & 1.23043 \\
.059 & 1.188 & .251 & 1.197 & 1.514 \\
.140 & .136 & -.046 & -.003 & 1.076 \\
1.00 & .140 & .140 & .140 & .140 \\
1.00 & 3.00 & 1.00 & 3.00 & 10.00 \\
2.00 & 1.00 & 1.00 & 1.00 & 1.00 \\
& 4.00 & 2.00 & 4.00 & 11.00
\end{tabular}

Table 11: Frequency table of Problems For women in educational sector

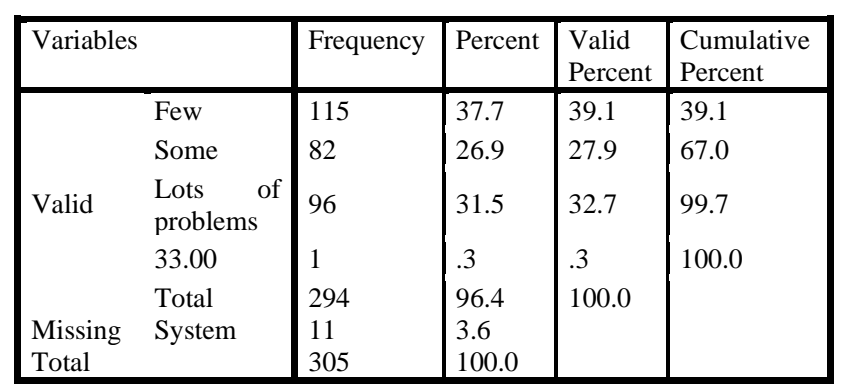

\section{DATA ANALYSIS}

Table 1 shows demographic characteristics of respondent. Majority of the respondents lie in the 21-25age groups having an experience of facing discrimination in education sector with the percentage of $39.7 \%$.

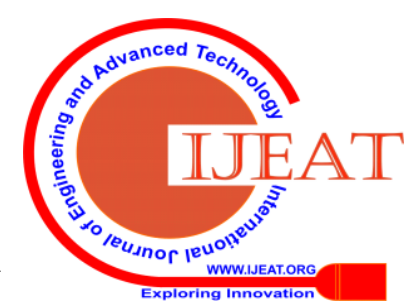




\section{Impact of Gender Discrimination on Professional life of Working Women in Education Sector of Haryana Universities}

And table 2 shows the female respondents with agree the inequality statement with $98.4 \%$. Table 3 and table 4 shown the qualification diploma frequency highest respondents with $26.9 \%$ and graduation only less than diploma $.8 \%$ and others higher qualification \% less than as compare to diploma and graduation and in marital status under married women $27.2 \%$ ,divorced women $27.9 \%$ facing the discrimination more rather than unmarried and widowed women. Table 5 shows the discrimination facing mostly those women husbands are not employer and businessman with $38.70 \%$ \& Table 6 family members more than $>4-6$ (28.5\%). Table 7 \& Table 8 shows family status with $51.1 \%$ and family income per annum $>2$ Lac -5 Lac (28.9\%). Table 9 shown residence status with $26.6 \%$ belongs to urban areas.

\section{LIMITATIONS}

The scope of this study is lack of testing of large sample of from choose district. Studies mostly based on quantitative, qualitative, questionnaires or survey. During the survey shortage of female faculty employees (respondents) participation in revealing the actual issues faced by them at the workplace, there are few limitations. This study focuses only on the experiences \& perspective of working female's only. That's why future research needs to be seen from the perspective of male employee's also \& the implementation of similar research in the future for confirming and refining the results of this study.

\section{CONCLUSION}

Gender discrimination is a hottest topic and issues not only in India, as a whole world. Gender inequality is mostly suffering by women and girls. In India time of baby girl birth discrimination is start and same environment on workplace. Female faculty too much problems suffered like mentally and physically harassment, negative environment, lose confidence, job dissatisfaction and job attitudes. Female faculty discriminated against because of race, religious, sex and age factor. In academic sector working women who work under the male management or seniors to do the work under the pressure.

\section{REFERENCES}

1. Sigala Maria and Himmelweit Susan, Published online by Cambridge University Press: 23 July 2004, Choice and the Relationship between Identities and Behavior for Mothers with Pre-School Children: Some Implications for Policy from a UK Study, DOI: https://doi.org/10.1017/S0047279404007779, Volume 33, Issue 3 ,July 2004, pp. 455-478.

2. Devaro Jed and Blau D.Francine, 7-1-2007, New Evidence on Gender Differences in Promotion Rates: An Empirical Analysis of a Sample of New Hires, Follow this and additional works at: https://digitalcommons.ilr.cornell.edu/articles.

3. Memon Zabin Nazia, June 2017, Gender Inequality, Job Satisfaction and Job Motivation: Evidence from Indian Female Employees, DOI: 10.1177/0258042X17718742.

4. Verniers Catherine and Vala Jorge, Published: January 9, 2018, Justifying gender discrimination in the workplace: The mediating role of motherhood myths, https://doi.org/10.1371/journal.pone.0190657,PP-1-23.

5. Yodanis L. Carrie, (C6,June 2004 Sage Publications, Gender Inequality, Violence Against Women, and Fear, DOI: 10.1177/0886260504263868, JOURNAL OF interpersonal violence, Vol. 19 No. , Page no. 655-675.
6. Zurbrügg and Miner N.Kathi, Front. Psychol., 02 May 2016 Gender, Sexual Orientation, and Workplace Incivility: Who Is Most Targeted and Who Is Most Harmed? | https://doi.org/10.3389/fpsyg.2016.00565.

7. Timmins Liadh, First Online: 22 July 2019, Minority Stressors, Rumination, and Psychological Distress in Lesbian, Gay, and Bisexual Individuals, The online version of this article ( https://doi.org/10.1007/s10508-019-01502-2) contains supplementary material, which is available to authorized users. pp $1-20$.

8. Dutta Sampurnaa, Mar - 2017, Indian Women in the Workplace: Problems and Challenges, international journal for innovative research in multidisciplinary field ISSN - 2455-0620 Volume - 3, Issue - 3, PP-152-159.

9. Russell ST,and Fish JN, 2016 May 31, Mental Health in Lesbian, Gay, Bisexual, and Transgender (LGBT) Youth, Published online 2016 Jan 14. doi: 10.1146/annurev-clinpsy-021815-093153, Page no. 465-487.

10. Bhattacharyya Arundhati July 2015, Indian Women in the Workplace Mediterranean Journal of Social Sciences ISSN 2039-9340(Print) ISSN 2039-2117(Online), Vol 6, No 4 DOI: 10.5901/mjss.2015.v6n4s2p118-125.

11. Sinden Elaine, 14 Nov 2017, exploring the Gap between Male and Female Employment in the South African Workforce, DOI: https://doi.org/10.1515/mjss-2017-0040, Volume 8: Issue 6, Pages: $37-51$

12. Herrbach Olivier and Mignonac Karim, 2012, Perceived Gender Discrimination and Women's Subjective Career Success: The Moderating Role of Career Anchors, https://www.jstor.org/stable/41634302, Vol. 67, No. 1 (WINTER 2012), pp. 25-50.

\section{AUTHORS PROFILE}

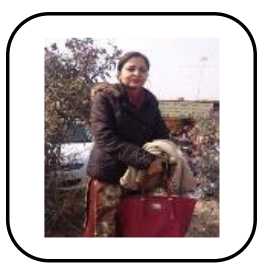

Deepa Sharma is a Research Scholar, Perusing Ph.D. from MMDU. She has 4 years work experience, as Assistant professor in Management. She has interested areas are Human Resource Management and

Dr.C.Venkateswaran has good academic experience about work. He is guiding $3 \mathrm{Ph} . \mathrm{D}$ research scholars presently. Now he

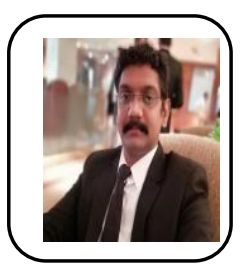
is working as assistant professor in, MMIM, Maharishi Markandeshwar (Deemed to be University).He has 11 years work experience in Human Resource field and Marketing. 